
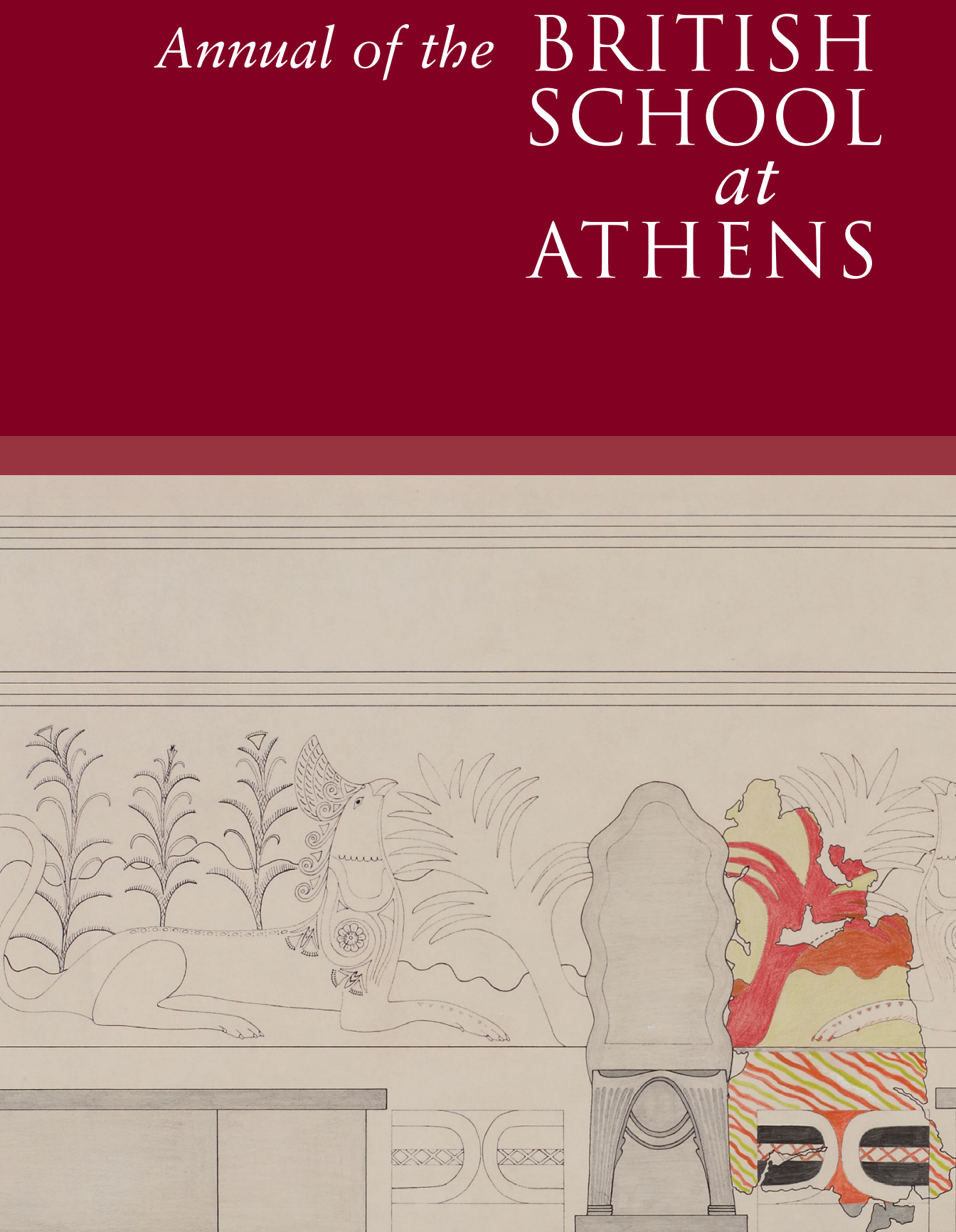

VOLUME $112 \cdot 2017$ 


\title{
THE BRITISH SCHOOL AT ATHENS
}

\section{REGISTERED CHARITY NO. 208673}

www.bsa.ac.uk

PATRON

HRH The Prince of Wales

\author{
CHAIR OF COUNCIL
}

Dr Carol Bell

DIRECTOR

Professor John Bennet, MA, PhD, FSA

The British School at Athens, an educational charity founded in 1886, forms part of the British Academy's network of British International Research Institutes (BIRI), which sustains and supports research overseas. The School promotes research of international excellence in all disciplines pertaining to Greek lands, from fine art to archaeometry, and in all periods to modern times. It does so through:

- a programme of research undertaken both alone and in collaboration with UK-based and other overseas institutions;

- an academic programme of seminars, lectures, and conferences;

- its internationally renowned library;

- the work of the Fitch Laboratory in science-based archaeological research across the Mediterranean;

- supporting the work of individual researchers from the UK and elsewhere, including applications for study and fieldwork permits; advice on the development of research programmes; accommodation and facilities in Athens and Knossos; and provision of online services;

- making their work known through the publication of its journals and monograph series;

- promoting the use of its archival, laboratory, and museum collections by the scholarly community worldwide;

- providing funding (including studentships and visiting fellowships) for research in Greece, and to enable Greek researchers to visit the UK;

- providing internships and training courses for undergraduates, postgraduates, and schoolteachers.

$\begin{array}{lll}\text { Athens: } & \text { Odos Souedias 52 } \\ \text { GR-106 76 Athens } & \text { School Office: } & \text { Tel: 0030-211-102 2800 } \\ \text { Greece } & \text { Fax: 0030-211-102 2803 } \\ \text { E-mail: admin@bsa.ac.uk }\end{array}$

Information for contributors to the Annual, including style guidelines, may be found at journals.cambridge.org/ath

The Annual of the British School at Athens is published by Cambridge University Press for the British School at Athens.

INDIVIDUAL SUBSCRIBERS

Individuals receive the Annual as part of membership of the School: further information on membership may be found at www.bsa.ac.uk.

\section{INSTITUTIONAL SUBSCRIPTION RATES}

The Annual of the British School at Athens (ISSN 0068-2454) is published once a year in December. The subscription price (excluding VAT) of volume 112 (2017), which includes print and online access, is $£ 119$ net (US\$193 in the USA, Canada and Mexico) for institutions. EU subscribers (outside the UK) who are not registered for VAT should add VAT at their country's rate. VAT-registered customers should provide their VAT registration number. Japanese prices for institutions (including ASP delivery) are available from Kinokuniya Company Ltd., P.O. Box 55, Chitose, Tokyo 156, Japan. All prices include delivery by air where appropriate.

Orders, which must be accompanied by payment, may be sent to a bookseller, subscription agent or direct to the publisher: Cambridge University Press, Journals Fulfillment Department, UPH, Shaftesbury Road, Cambridge CB2 8BS, UK, e-mail journals@cambridge.org; or in the USA, Canada and Mexico: Cambridge University Press, Journals Fulfillment Department, Cambridge University Press, 1 Liberty Plaza, Floor 20, New York, NY 10006, USA, e-mail subscriptions_newyork@ cambridge.org.

\section{COPYING}

This journal is registered with the Copyright Clearance Center, 222 Rosewood Drive, Danvers, MA 01923, USA. Organisations in the USA who are registered with the C.C.C. may therefore copy material (beyond the limits permitted by sections 107 and 108 of the U.S. Copyright law) subject to payment to the C.C.C. of the per copy fee of $\$ 30$. This consent does not extend to multiple copying for promotional or commercial purposes. Code 0068-2454/2016. ISI Tear Sheet Service, 3501 Market Street, Philadelphia, PA 19104, USA, is authorised to supply single copies of separate articles for private use only. Organisations authorised by the Copyright Licensing Agency may also copy material subject to the usual conditions. For all other use, permission should be sought from Cambridge or from the North American Branch of Cambridge University Press.

The journal is included in the Cambridge Journals Online service which can be found at http://journals.cambridge.org.

This journal has been printed on FSC-certified paper and cover board. FSC is an independent, non-governmental, non-for-profit organisation established to promote the responsible management of the world's forests. Please see www.fsc.org for information.

(C) The British School at Athens, 2017 


\section{THE ANNUAL OF THE \\ BRITISH SCHOOL AT ATHENS \\ NO. II 2 \\ 2017}

Published by Cambridge University Press

on behalf of the Council of the British School at Athens

Co-Editors:

Peter Liddel and John Bennet 
(C) The Council, British School at Athens, 2017

ISSN 0068-2454

Front cover image

CAM 523- North Wall, Throne Room Fresco, Knossos; Mark Cameron Personal Papers; BSA Archive 


\section{CONTENTS}

Dora Katsonopoulou and Stella Katsarou, Mainland Cosmopolitanism and the Rise of Personal Prestige: New Evidence from the Coastal Early Helladic Town of Helike, North-West Peloponnese, Greece

J.W. SHaw, Access to Upper Floors and an Early Light Well at EM II Vasiliki

Yannis Galanakis, Efi Tsitsa and Ute Günkel-Maschek, The Power of Images: Re-Examining the Wall Paintings from the Throne Room at Knossos

Alexandra Villing and Hans Mommsen, Rhodes and Kos: East Dorian Pottery Production of the Archaic Period

Lisa C. Nevett, E. Bettina Tsigarida, Zosia H. Archibald, David L. Stone, Timothy J. Horsley, Bradley A. Ault, Anna Panti, Kathleen M. Lynch, Hannah Pethen, Susan M. Stallibrass, Elina Salminen, Christopher Gaffney, Thomas J. Sparrow, Sean Taylor, John Manousakis and Dimitrios Zekkos, Towards a Multi-Scalar, Multidisciplinary Approach to the Classical Greek City: The Olynthos Project

Rebecca Sweetman, Networks and Church Building in the Aegean: Crete, Cyprus, Lycia and the Peloponnese

J. Baker, V. Kantarelou, A.G. Karydas, R.E. Jones, P. Siozos, D. Anglos and B. Derham, The Height of Denier Tournois Minting in Greece (I289-I3I3) According to New Archaeometric Data

Fotini Kondyli, Lords at the End of the Empire: Negotiating Power in the Late Byzantine Frontiers (Fourteenth-Fifteenth Centuries)

Georgia Flouda, Archaeology in the War Zone: August Schörgendorfer and the Kunstschutz on Crete During World War II

David R. Hernandez, Battling Water: The Frontiers of Archaeological Excavations at Butrint (1928-2014) 